Orissa Journal of Commerce

Vol. 42, Issue 1, Jan-March 2021

ISSN: 0974-8482

(C) OJC India. All Right Reserved

URL : www.ojcoca.org

DOI: https://doi.org/10.54063/ojc.2021.v42i01.03

\title{
Did the Outbreak of COVID-19 Change the Volatility of Hospitality Stocks? An Investigation through Beta Stationarity Approach
}

\author{
Bidisha Datta $^{1^{*}}$ and Indranil Sarker ${ }^{2}$ \\ ${ }^{1}$ Assistant Professor, Department of BBA, Asutosh College, Kolkata, West Bengal.E-mail: bidishadatta@rediffmail.com \\ ${ }^{2}$ Lead Product Consultant, Cognizant Technology Solutions, Kolkata, West Bengal. E-mail: forcorrespondence@gmail.com \\ ${ }^{*}$ Corresponding Author
}

To cite this paper

Datta, B., \& Sarker, I. (2021). Did

the Outbreak of COVID-19

Change the Volatility of

Hospitality Stocks? An

Investigation through Beta

Stationarity Approach. Orissa

Journal of Commerce. 42(1), 29-43.

Keywords

COVID-19, Hospitality stocks,

Volatility, Beta stationarity,

Tourism

JEL Classification

G14, G15, G17

\begin{abstract}
The hospitality sector is amongst the worst affected sectors due to COVID-19. In this study, we investigated whether the COVID-19 outbreak led to any significant change in sensitivity of hospitality stock indices of two top international tourist destinations that are also among the worst affected by the COVID-19 pandemic. Daily closing returns of the hospitality index were regressed on that of the broad-based market index to identify existence of linear relationship between the two variables. Thereafter the stationarity of beta of the hospitality index was evaluated. Results indicate that the COVID-19 outbreak has negatively affected the volatility of hospitality sector stocks. Beta stationarity was found for one country but not for the other. The study also revealed that information absorption regarding the COVID19 outbreak in the hospitality sector stock prices were triggered at different time points in different countries. The results contribute to an understanding of investors regarding selecting appropriate global markets for investment purposes.
\end{abstract}

\section{Introduction}

The COVID-19 pandemic, also termed as coronavirus pandemic, has spilled over to all aspects of existence and converted into a severe economic crisis, massive loss of employment, unmatched loss of academic days, severe social disruption, closure of all sporting, religious \& political events, overflow of misleading information and splurge of xenophobia amongst others.

China country office of World Health Organization (WHO) was informed about the disease on 31 December 2019. Subsequently, WHO declared a pandemic on 11 March 2020 (Joel Shannon, 2020). There is a consensus that the hospitality industry is and will continue to remain the most brutal hit (United Nations World Tourism Organisation, 2020). Tourism is at the same time a catalyst for the spread of viruses and a victim of their spread too (Mensah, 2020).

As for research work on hospitality, tourism much work has already been done on the impact that these industries are facing due to lockdown and restrictions (Hoque, Shikha, Hasanat, Arif, \& Hamid, 
2020; Zheng, Goh, \& Wen, 2020; Chinazzi M., et al., 2020; Kasare, 2020). However, we could not find any work on the impact of COVID-19 on the 'stocks' of the hospitality industry. Hospitality stocks are presumed to be riskier than other categories of stocks (Park, 2013). Hence the extent of fall in the prices of hospitality stocks is expected to be more than the extent of fall in the prices of the overall market index. The term "riskiness" mainly refers to market-related risk. The most common measure of this is the beta coefficient (Sharpe, 2018; Babcock, 1972; Jagannathan \& Wang, 2002). Conceptually speaking, beta measures a stock/ portfolio percentage price change given a one percent change in the market index (Levy, 1971). This paper aims to investigate if the riskiness of hospitality stocks were higher in context to the overall markets. For this purpose, it works on secondary data on daily closing prices of country-specific hospitality index and broad-based market index. First, daily closing returns of the hospitality index were regressed on that of the broad-based market index to determine the linear relationship between the two variables. After that, the stationarity of beta of the hospitality index was evaluated. This study is expected to be exemplary in nature since this work, to the best of our understanding, is a novel attempt to investigate the nature of stationarity of beta of hospitality industry securities.

\section{Review of Literature}

Levy (1971) indicated beta was stationary for large portfolios, less stationery for smaller portfolios, and unpredictable in case of individual securities. Further, a distinct tendency was seen for the betas to regress towards their means; this tendency was stronger for high-risk portfolios than for low-risk portfolios. Blume (1975) too concluded that beta coefficients tend to regress towards the grand mean of all betas over time. He also demonstrated that though measurement error existed, it did not significantly influence the stationarity/ non-stationarity nature of betas. Gooding and Malley (1977) revealed that the betas for individual securities were higher during the two bull markets than during the two bear markets.

However, Fabozzi and Francis (1977) revealed that none of alpha or beta is significantly different between bear and bull markets. Therefore, they argued that using a time series analysis, which allows beta to change during the estimation period, would be a better approach than evaluating the stationarity of beta within a given period. Bey (1978) commented that the time trending tests showed that betas of the extremely low (high) risk portfolios became larger (smaller) over time. Hsu (1984) showed shifts in market return and instability of the single-index beta coefficient. Thus, he concluded that stock market risk is evolutionary and not stationary. Again, Simon, Pagini, and Decourt concluded that their evidence pointed to a very low level of stationarity of beta coefficients of companies. In a research conducted on the Turkish stock exchange, Odabasi (2000) explored the issue of beta stationarity on the Istanbul Stock Exchange. The tests indicated that portfolios' beta stability increases as the portfolio size gets larger.

Rahman, Ezaj, and Akbar examined the stationarity of individual and portfolio beta over bullish and bearish market phases of 100 listed companies at the Karachi stock exchange between 2004 to 2009. They concluded that both individual and portfolio betas remain stationary and do not change with the changing bullish and bearish market trends. Dash and Sundarka (2015) too tested the stationarity 
of beta for Automotive and Auto-Ancillary sector stocks in the Indian stock market using the univariate ANCOVA/General Linear Model. The results of their study supported the hypothesis of beta stationarity. The instability of market beta was harped upon by Jawadi et al. (2019), who concluded that market beta is time-varying and alters time varyingly and asymmetrically. Kayo et al. (2020) concluded that pure-play beta is similar to the unobservable systematic risk of a sector, and beta stability is sturdily related to the length of the estimation window. Wang (2021) says that the beta of the banking industry is time-varying, and its relationship with return is regime dependent.

\section{Objectives of the Study}

In this study, instead of individual hospitality stocks, we have assessed the beta stationarity of the hospitality index (which can be considered a portfolio of hospitality stocks). Furthermore, we have chosen two out of the top ten tourist destinations (based on international tourist arrival) of the world (World Tourism Barometer, 2018), Spain and the USA, since the national stock exchanges of these countries have travel and tourism indices that would be an appropriate basis of comparison with an overall market index. In addition, these two countries are within the top 20 worst-affected countries due to the COVID-19 outbreak as per the total number of affected cases as of 8 June 2020 (Worldometer COVID-19 Coronarius Pandemic, 2020). Based on the rationale of the study, the research objectives are:

- To understand the impact of COVID-19 on the stationarity of the beta of the hospitality index for selected top two international tourist destination countries.

- To analyse if the hospitality industry stocks were impacted at around the same time across different countries.

- To evaluate if the COVID-19 outbreak led to any structural breaks in the relationship between the hospitality index and market index returns.

\section{Research Methodology}

\subsection{Sample Period}

This study has been conducted for the period 1 January 2019 to 5 Jun 2020. The first nine months and the following three months of the calendar year 2019 have been regarded as the base period and pre COVID-19 period, respectively. In addition, two trigger points regarding the outbreak of COVID-19 have been considered. One is when COVID-19 was reported by China to WHO China office and another when COVID-19 was declared as a pandemic by WHO. Accordingly, the overall period of study has been divided into four distinct stages for performing the analysis. (Refer Table 1).

\subsection{Data Sources}

World Tourism rankings compiled by United Nations World Tourism Organization have been taken for the rankings. The degree of impact of COVID-19 on these shortlisted countries was sourced from the website of 'Wordometers.info'. The daily closing prices of the hospitality index and the broadbased market index were collected from the website of 'Investing.com' (Refer Table 2 and 3). 
Bidisha Datta and Indranil Sarker

Table 1: Sample Period and Different Stages Considered in the Study

\begin{tabular}{|c|c|c|}
\hline Stage & Time Period & Details \\
\hline Stage 0 & $1^{\text {st }} \operatorname{Jan} 2019-30^{\text {th }}$ Sep 2019 & 9 months period prior to Stage 1 \\
\hline Stage 1 & $1^{\text {st }}$ Oct $2019-31^{\text {st }}$ Dec 2019 & $\begin{array}{l}3 \text { months period immediately prior to reporting of COVID-19 } \\
\text { by China to WHO, China }\end{array}$ \\
\hline Stage 2 & $1^{\text {st }} \operatorname{Jan} 2020-11^{\text {th }}$ Mar 2020 & $\begin{array}{l}2.5 \text { months period between China reporting to WHO and WHO } \\
\text { declaring COVID-19 as a pandemic }\end{array}$ \\
\hline Stage 3 & $12^{\text {th }}$ Mar $2020-5^{\text {th }}$ Jun 2020 & 3 months period post WHO declaring COVID-19 as a pandemic \\
\hline
\end{tabular}

Table 2: Ranking of the Shortlisted Countries Regarding International Tourist Arrivals and the Impact of the COVID-19 Pandemic

\begin{tabular}{|c|c|c|c|c|c|c|c|}
\hline \multirow[t]{2}{*}{ SlNo } & \multirow[t]{2}{*}{ Country } & \multicolumn{2}{|c|}{ Tourism Statistics } & \multicolumn{4}{|c|}{ Coronavirus Statistics } \\
\hline & & $\begin{array}{l}\text { Rank } \\
(2018)\end{array}$ & $\begin{array}{l}\text { Rank } \\
(2017)\end{array}$ & $\begin{array}{c}\text { Rank } \\
\text { (Total Cases) }\end{array}$ & $\begin{array}{c}\text { Rank } \\
\text { (Total Cases/ } \\
1 M \text { Pop) }\end{array}$ & $\begin{array}{c}\text { Rank } \\
\text { (Total Death) }\end{array}$ & $\begin{array}{c}\text { Rank } \\
\text { (Total Death/ } \\
1 M \text { Pop) }\end{array}$ \\
\hline 1 & Spain & 2 & 2 & 4 & 11 & 6 & 5 \\
\hline 2 & $\begin{array}{l}\text { USA of America of } \\
\text { America of America }\end{array}$ & 3 & 3 & 1 & 12 & 1 & 12 \\
\hline
\end{tabular}

Source: Data as on 7 June 2020; UNTWO website and worldometers website

Table 3: Country-wise Listing of the Indices Considered for Analysis under this Study

\begin{tabular}{llll}
\hline SlNo & Country & Hospitality Index & Broad-Based Market Index \\
\hline 1 & Spain & BCN 5 Commerce Leisure and Tourism & IBEX 35 \\
2 & USA & Dow Jones Travel \& Tourism & Dow Jones Industrial Average \\
\hline
\end{tabular}

Source: https:/ / www.investing.com

\subsection{Tools and Techniques}

The daily closing prices were used for calculating the daily returns for both the hospitality index and the broad-based market index. The formulae used for the same was as follows:

$$
R_{t}=L N\left(\frac{P_{t}}{P_{t-1}}\right)
$$

Where $\mathrm{R}_{\mathrm{t}}=$ Returns of the index on trading day $\mathrm{t}$

$\mathrm{P}_{\mathrm{t}}{ }_{\mathrm{t}}=$ Closing Price of the index on trading day $\mathrm{t}$

$\mathrm{P}_{\mathrm{t}-1}=$ Closing Price of the index on the trading day before day $\mathrm{t}$ 
The daily closing returns of the hospitality index and the broad-based market index were first checked for stationarity based on the following criteria: Augmented Dickey-Fuller test; Lag order: 16; Criterion: AIC; Test statistic: Tau.

The daily closing returns of the hospitality index and the broad-based market index were found to be stationary for all the countries studied.

After that, the daily closing returns of the hospitality index were regressed on that of the broadbased market index by using the OLS method (for the overall period of study) to determine the linear relationship between these two variables. For this, the initial form of equation considered was as follows:

$$
E(r)_{H_{t}}=\alpha+\beta \times E(r)_{M I_{t}}+\varepsilon
$$

where $E(r)_{\mathrm{HI}_{t}}=$ Expected daily returns of the hospitality index on trading day $\mathrm{t}$

$\alpha=$ Intercept i.e., Trend

$\beta=$ Beta of the hospitality index

$E(r)_{M I_{t}}=$ Expected daily returns of the broad-based market index on trading day $\mathrm{t}$

$\varepsilon=$ Error term

The validity of the regression model, as derived above, was evaluated based on the following criteria:

a. No autocorrelation between the residuals (Breusch-Godfrey test for autocorrelation; Test statistic: LM).

b. No heteroscedasticity of the residuals (Breusch-Pagan test for heteroscedasticity -robust variant); Test statistic: LM).

For validation of the regression model, we did not consider the test for normality of residuals because of the following reasons it has been empirically observed that data on stock returns seldom follow a normal distribution. The sample size here was significantly large (more than 350 paired data points). The test for the fixed variance of residuals was instead considered.

If either of the above two criteria were not satisfied, the regression model was modified by adding lagged regressors. First, the autocorrelation and partial autocorrelation plots of the daily closing returns of the hospitality index and the broad-based market index were considered for identifying the lags to be included in the model. Then, the optimum regression model was determined on a trial-anderror approach based on the statistical significance of the coefficients of the lagged regressors added to the model. After that, the stationarity of beta of the hospitality index was evaluated based on the following criteria: Chow test for structural break; Test statistic: $F$

The structural break was studied at the beginning of each of stages 1, 2 and 3

(a) Stage 1: $1^{\text {st }}$ Oct 2019 or next available trading day.

(b) Stage 2: $2^{\text {nd }}$ Jan 2020 or next available trading day.

(c) Stage 3: $12^{\text {th }}$ Mar 2020 or next available trading day.

The absence of structural break in the overall data set meant stationarity of beta of the hospitality index, thereby suggesting that the spread of COVID-19 did not significantly impact the sensitivity of the hospitality index (and stocks) of that particular country. 
On the contrary, the presence of structural break indicated the non-stationarity of the beta of the hospitality index, which, as per the design of the study, could be attributed to the spread of COVID19 in that particular country.

For countries where the Chow test could not find a structural break, the finalized regression model was re-run using periodic dummy variables against each stage to revalidate the findings of the Chow test.

\section{Results Analysis and Findings}

\subsection{Statistical Data Analysis of Daily Returns of the Hospitality Index and the Broad-based Market Index for the Overall Period of Study for Spain}

This section delves in details about the nature of descriptive statistics of the daily returns of the hospitality index and the broad-based market index for Spain. Thereafter, the regression analysis has been done and existence of structural break point has been investigated.

\subsubsection{Descriptive Statistics}

The descriptive statistics of the daily returns of the hospitality index and the broad-based market index for the overall period of study for the Spain was studied to understand the basic features of the data.

Table 4: Summary Statistics of the Daily Returns of the Hospitality Index and the Broad-based Market Index for the Overall Period for Study (Spain)

\begin{tabular}{lcccccc}
\hline & Mean & Median & Minimum & Maximum & SD & $\begin{array}{c}\text { Correlation } \\
\text { with Market }\end{array}$ \\
\hline Market Index & -0.022 & 0.050 & -15.151 & 7.527 & 1.654 & 1.000 \\
Hospitality Index & -0.094 & -0.002 & -21.567 & 14.717 & 2.701 & 0.729 \\
\hline
\end{tabular}

Source: Authors' Calculation

The results indicated that the hospitality index demonstrated much higher volatility and lower returns compared to the broad-based market index. Also, the average daily returns for the broad-based market index as well as the hospitality index were both negative. The daily returns of the hospitality index were positively correlated with the daily returns of the broad-based market index.

\subsubsection{Regression Analysis of Hospitality Index (Spain) on Broad based Market Index}

The finalized regression model was as follows:

$$
E(r)_{L T_{t}}=1.19 \times E(r)_{I B E X_{t}}+\varepsilon
$$

where, $E(r)_{L T_{t}}=$ Expected daily return of BCN 5 Commerce Leisure and Tourism Index on trading day $\mathrm{t}$

$E(r)_{I B E X_{t}}==$ Expected daily return of IBEX 35 Index on trading day $\mathrm{t}$ and 
$\varepsilon=$ Error term

The Chow test revealed a structural break at the beginning of Stage3 (12 Mar 2020).

Hence, the regression model for pre-COVID-19 incidence was as follows:

$$
E(r)_{L T_{t}}=0.92 \times E(r)_{I B E X_{t}}+\varepsilon
$$

Where, the time period considered was 3 Jan 2019 to 11 Mar 2020

In addition, the regression model for post-COVID-19 incidence was as follows:

$$
E(r)_{L T_{t}}=1.32 \times E(r)_{I B E X_{t}}+\varepsilon
$$

Where, the time period considered was 12 Mar 2020 to 5 Jun 2020

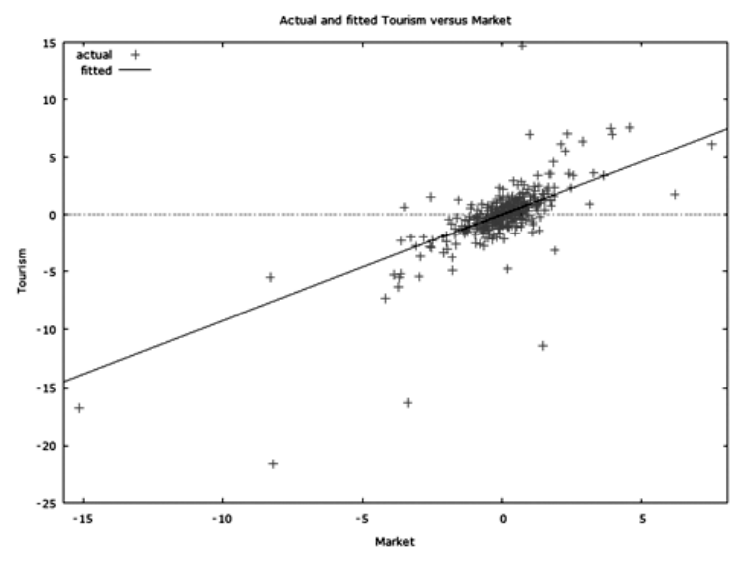

$3^{\text {rd }}$ Jan 2019 to $11^{\text {th }}$ Mar 2020

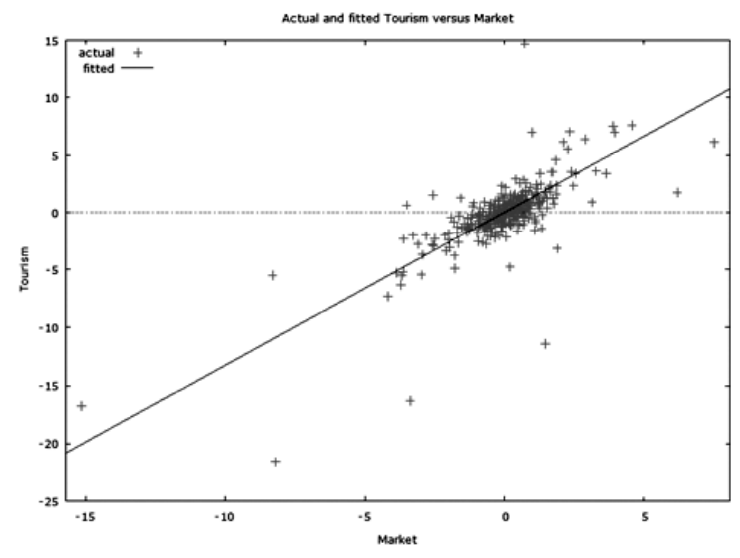

$12^{\text {th }}$ Mar 2020 to $5^{\text {th }}$ Jun 2020

Figure 1: Time Series Plot of returns of Hospitality Index (Tourism) and broad-based Market Index (Market) - both actual and predicted values (Spain)

Source: Authors' Calculation

The analysis indicates that Beta was not stationary for the overall time period of study. Beta was not stationary for the overall time period of study. A structural break in the relationship between daily returns of the hospitality index and the broad-based market index after WHO declared COVID-19 as a pandemic. Post incidence of COVID-19, there was a significant rise (43\%) in the beta value for the hospitality index, thereby indicating an increase in sensitivity of hospitality stocks to market movements.

5.2. Statistical Data Analysis of Daily Returns of the Hospitality Index and the Broad-based Market Index for the Overall Period of Study for USA

\subsubsection{Descriptive Statistics}

The descriptive statistics of the daily returns of the hospitality index and the broad-based market index for the overall period of study for the USA was studied to understand the basic features of the data. 
Bidisha Datta and Indranil Sarker

Table 5: Summary Statistics of the Daily Returns of the Hospitality Index and the Broad-based Market Index for the Overall Time Period for Study (USA)

\begin{tabular}{lcccccc}
\hline & Mean & Median & Minimum & Maximum & SD & $\begin{array}{c}\text { Correlation with } \\
\text { Market }\end{array}$ \\
\hline Market Index & 0.041644 & 0.10125 & -13.842 & 10.764 & 1.9046 & 1.0000 \\
Hospitality Index & 0.0014577 & 0.18257 & -13.400 & 11.494 & 2.5506 & 0.7821 \\
\hline
\end{tabular}

Source: Authors' Calculation

The above table indicates that the hospitality index of USA demonstrated higher volatility and lower returns compared to the broad-based market index. The average daily returns for the broadbased market index as well as the hospitality index were both positive. The daily returns of the hospitality index were positively correlated with the daily returns of the broad-based market index.

\subsubsection{Regression Analysis of Hospitality Index (USA) on Broad based Market Index}

The finalized regression model was as follows:

$$
E(r)_{T T_{t}}=1.04 \times E(r)_{D J_{t}}+\varepsilon
$$

where, $E(r)_{T T_{t}}=$ Expected daily return of Dow Jones Travel \& Tourism Index on trading day $\mathrm{t}$

$E(r)_{D J_{t}}=$ Expected daily returns of Dow Jones Industrial Average Index on trading day $\mathrm{t}$ and $\varepsilon=$ Error term

The Chow test revealed no structural break at beginning of any of the three stages. This was also validated when the finalized regression model was re-run using periodic dummy variables for all the stages. (Refer Figure 2)

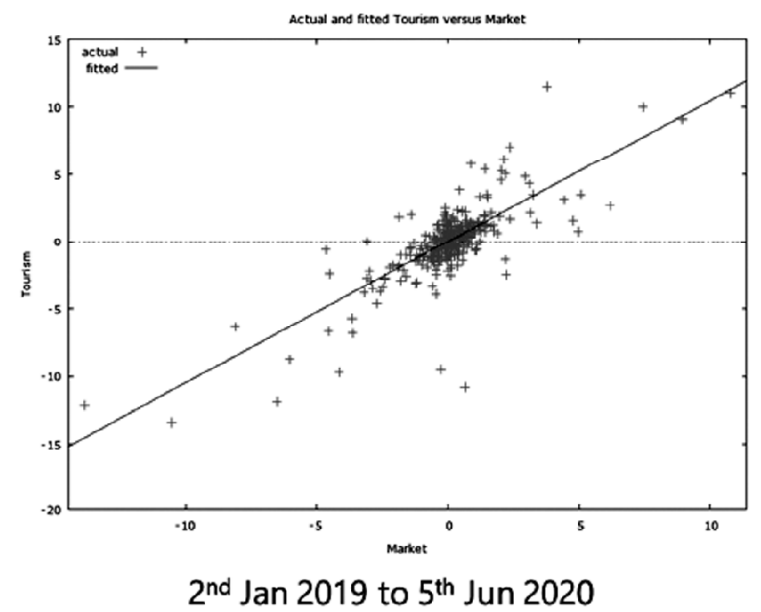

Figure 2: Time Series Plot of returns of Hospitality Index (Tourism) and broad-based Market Index (Market) - both actual and predicted values (USA)

Source: Authors' Calculation 
The above analysis indicates that beta was stationary for the overall time period of study. There was no significant change in the sensitivity of the hospitality index (vis-à-vis hospitality stocks) to market movements due to the incidence of COVID-19 for USA.

All the statistical test conducted for both the countries and the corresponding results thereof have been elaborated in the following tables (Table 6,7 and 8)

Table 6: Detailed Statistical Parameters of the Finalized OLS Regression Model between Hospitality Index (Tourism) and Broad-based Market Index (Market)

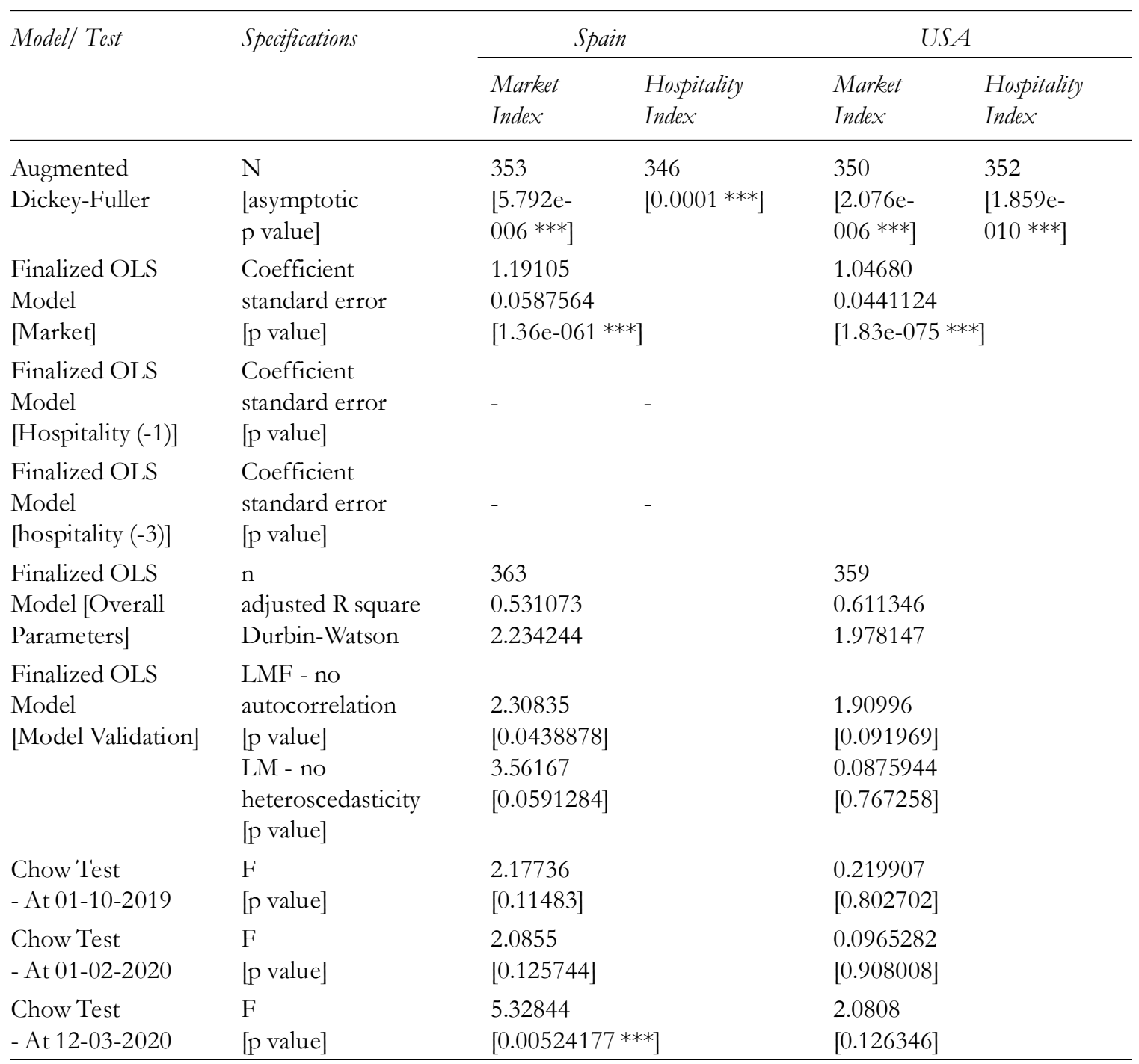

Source: Authors' Calculation 
Bidisha Datta and Indranil Sarker

Table 7: Updated OLS Regression Model between Hospitality Index (Tourism) and Broad-based Market Index (Market) by Introducing Dummy Variables for Each Stage of Analysis

\begin{tabular}{|c|c|c|c|}
\hline Model/ Test & Specifications & Spain & $U S A$ \\
\hline $\begin{array}{l}\text { Updated OLS Model } \\
\text { [Market] }\end{array}$ & $\begin{array}{l}\text { coefficient } \\
\text { standard error } \\
\text { [p value }]\end{array}$ & - & $\begin{array}{l}1.04106 \\
0.0443387 \\
{[3.05 \mathrm{e}-074 \text { ***] }}\end{array}$ \\
\hline $\begin{array}{l}\text { Finalized OLS Model } \\
{[\text { Hospitality }(-1)]}\end{array}$ & $\begin{array}{l}\text { coefficient } \\
\text { standard error } \\
\text { [p value }]\end{array}$ & - & - \\
\hline $\begin{array}{l}\text { Finalized OLS Model } \\
\text { [hospitality }(-3)]\end{array}$ & $\begin{array}{l}\text { coefficient } \\
\text { standard error } \\
\text { [p value] }\end{array}$ & - & - \\
\hline $\begin{array}{l}\text { Updated OLS } \\
\text { Model [Stage1] }\end{array}$ & $\begin{array}{l}\text { coefficient } \\
\text { standard error } \\
\text { [p value] }\end{array}$ & - & $\begin{array}{l}-0.0939871 \\
0.198934 \\
{[0.6369]}\end{array}$ \\
\hline $\begin{array}{l}\text { Updated OLS } \\
\text { Model [Stage2] }\end{array}$ & $\begin{array}{l}\text { coefficient } \\
\text { standard error } \\
\text { [p value] }\end{array}$ & - & $\begin{array}{l}-0.302761 \\
0.230346 \\
{[0.1896]}\end{array}$ \\
\hline $\begin{array}{l}\text { Updated OLS } \\
\text { Model [Stage3] }\end{array}$ & $\begin{array}{l}\text { coefficient } \\
\text { standard error } \\
\text { [p value] }\end{array}$ & - & $\begin{array}{l}0.156200 \\
0.205679 \\
{[0.4481]}\end{array}$ \\
\hline $\begin{array}{l}\text { Finalized OLS Model } \\
\text { [Overall Parameters] }\end{array}$ & $\begin{array}{l}\mathrm{n} \\
\text { adjusted R square } \\
\text { Durbin-Watson }\end{array}$ & - & $\begin{array}{l}359 \\
0.614088 \\
1.989017\end{array}$ \\
\hline
\end{tabular}

Source: Authors'Calculation

Table 8: Modified OLS Regression Model between Hospitality Index (Tourism) and Broad-based Market Index (Market) before and after the Trigger Point for Structural Change

\begin{tabular}{lllll}
\hline Model Test & Specifications & Spain & USA \\
\cline { 3 - 5 } & & Pre COVID-19 & Post COVID-19 & NA \\
\hline Updated OLS & coefficient & 0.922766 & 1.32346 & - \\
Model & standard error & 0.0673304 & 0.139922 & - \\
[Market] & [p value] & {$\left[1.35 \mathrm{e}-033^{* * *}\right]$} & {$[2.34 \mathrm{e}-013 * * *]$} & \\
Finalized OLS & coefficient & & & - \\
Model & standard error & - & & \\
[hospitality $(-1)]$ & {$[$ value] } & & & \\
\hline
\end{tabular}

contd. table 8 
Did the Outbreak of COVID-19 Change the Volatility of Hospitality Stocks?

\begin{tabular}{|c|c|c|c|c|}
\hline \multirow[t]{2}{*}{ Model/ Test } & \multirow[t]{2}{*}{ Specifications } & \multirow{2}{*}{$\frac{\text { Spain }}{\text { Pre COVID-19 }}$} & \multicolumn{2}{|l|}{ USA } \\
\hline & & & Post COVID-19 & $N A$ \\
\hline Finalized OLS & $\mathrm{n}$ & 304 & 59 & \\
\hline Model [Overall & adjusted $\mathrm{R}$ square & 0.378878 & 0.606660 & - \\
\hline Parameters] & Durbin-Watson & 1.907681 & 2.411830 & \\
\hline Finalized OLS & LMF - no & & & \\
\hline Model [Model & autocorrelation & 0.53318 & 1.3978 & \\
\hline \multirow[t]{3}{*}{ Validation] } & [p value] & {$[0.751104]$} & [0.240148] & \\
\hline & LM - no & 1.28426 & 1.56929 & - \\
\hline & $\begin{array}{l}\text { heteroscedasticity } \\
\text { [p value] }\end{array}$ & [0.257109] & [0.21031] & \\
\hline
\end{tabular}

Source: Authors' Calculation

\subsubsection{Regressory Trend of Observed Beta Values}

Irrespective of the fact, whether the beta of the countries studied was stationary or not, two trends were strongly evident for the beta of the hospitality indices of both countries studied. First, beta for each country displayed an upward trend across all the four stages studied. Second, beta for both countries showed a regressory trend across all the four stages studied (Table 9)

Table 9: Beta of Hospitality Indices for each Country Over the Total Period Studied and each Stage

\begin{tabular}{lcccc}
\hline Country/Total Period & Stage 0 & Stage 1 & Stage 2 & Stage 3 \\
\hline Spain & 0.864422 & 1.27269 & 0.874833 & 1.32346 \\
USA & 1.09828 & 0.508693 & 0.872298 & 1.10468 \\
\hline
\end{tabular}

Source: Authors' Calculation

\section{Conclusion}

Beta remained stationary for the USA and not for Spain. However, for Spain, the declaration of COVID-19 as a pandemic by WHO triggered a shift from the current beta. As a result, the hospitality stocks became much more sensitive to market movements in Spain (three months post declaration of COVID-19 as a pandemic). At the same time, stability prevailed in the Stock prices in the USA.

The results strongly indicate that the COVID-19 outbreak has negatively affected the volatility of hospitality sector stocks. In the USA, this has led to shifts in volatility (beta values trending upwards without change in beta stationarity), signifying temporary departures from existing volatility levels. In Spain, this has led to and change in volatility (change in beta stationarity with upward rise), signifying permanent departures from existing volatility levels. The upwards trend in beta suggests that these markets are fit for investors with a higher risk appetite. The prevalent regressory trend implies that the markets are riskier but predictable and hence are good investment options. A higher beta may aid in 
generating higher returns and achieving faster recovery. However, the investors' perception towards these stocks is bound to alter given the dynamics of change, which will influence the demand and supply of these stocks, which will influence the recovery trend of these stocks. That would be an exciting area of further research. Besides, why the stock beta stationarity varied for the two countries can be further researched by studying other variables affecting the economy and can be pursued for further research too.

A limitation of this study is that it encompasses only two countries. Including more countries can give a more vivid picture of the investment scenario. Finally, the study also revealed that information absorption regarding the COVID-19 outbreak in the hospitality sector stock prices was triggered at different time points in different countries.

\section{References}

Ahmad, T. (2020, April 5). Corona Virus (COVID-19) Pandemic and Work from Home: Challenges of Cybercrimes and Cybersecurity. SSRN. doi: Ahmad, Tabrez, Corona Virus (COVID-19) Pandemic and Work from Home: Challenges of Cybercrimes and Cybersecurity (April 5, 2020)10.2139/ssrn.3568830.

Ahn, D.-g., Shin, H.-j., Kim, M.-h., Lee, S., Kim, H.-s., Myoung, J., Kim, S.-j. (2020). Current Status of Epidemiology, Diagnosis, Therapeutics, and Vaccines for Novel Coronavirus Disease 2019 (COVID-19). Journal of Microbiology and Biotechnology, 27(11), 313-324.

Babcock, G. (1972, June). A Note on Justifying Beta as a Measure of Risk. Journal of Finance, 27(3), 699-702. doi: $10.2307 / 2978270$

Bey, R. P. (1978). The Stationarity of beta: A Re-Examination of Recent Findings. University of Illinois.

Blume, M. E. (1975). Betas and Their Regression Tendencies. The Journal of Finance, 785-795.

Breusch, T. S. (1978). Testing for Autocorrelation in Dynamic Linear Models. Australian Economic Papers, 334-355.

Cantore, N., Hartwich, F., Lavopa, A., Haverkamp, K., Laplane, A., \& Rodousakis, N. (2020). Coronavirus: the economic impact. United Nations Industrial Development Organisation.

Centres for Disease Control and Prevention. (2020). Retrieved from www.cdc.gov.

Chinazzi, M., Davis, J., Ajelli, M., Gioannini, C., Litvinova, M., Merler, S., Vespignani , A. (2020, April 24). The effect of travel restrictions on the spread of the 2019 novel coronavirus (COVID-19) outbreak. Science, 368(6489), 395-400.

Chow, G. C. (1960). Tests of Equality between Sets of Coefficients in Two Linear Regressions. Econometrica, 591605.

Cohen, J. (2020, April 3). Vaccine designers take first shots at COVID-19. Science, 368(6486), 14-16. doi: 10.1126/ science.368.6486.14

Dash, M., \& Sundarka, S. S. (2015). Testing the Stationarity of Beta for Automotive and Auto-Ancillary Sector Stocks in Indian Stock Market. Journal of Applied Management and Investments.

Dawn. (2020, June 6). What is the birthplace of COVID-19? China, US at loggerheads over virus origin. Retrieved from www.dawn.com: https://www.dawn.com/news/1540589

Dr. Nils Redeker. (2020). Flattening the Recession Curve-Comparing Initial Fiscal Responses to the. Europe.

Ejaz, S., \& Akbar, M. (n.d.). Stability of Beta over Different Market Phases: An Empirical Study of Pakistani Equity Market. 
Fabozzi, F. J., \& Francis, J. C. (1977). Stability Tests for Alphas and Betas over Bull and Bear Market Conditions. Journal of Finance, 1093-1099.

Fang, H., Wang, L., \& Yang, Y. (2020). Human Mobility Restrictions and the Spread of the Novel Coronavirus (2019-nCoV) in China. Wuban: The national bureau of economic research.

Fernandes, N. (2020, March 23). Economic Effects of Coronavirus Outbreak (COVID-19) on the World Economy. Retrieved from papers.ssrn.com: https://papers.ssrn.com/sol3/papers.cfm?abstract_id=3557504

Fetzer, T., Hensel, L., Hermle, J., \& Roth, C. (2020, March 21). Coronavirus perceptions and economic anxiety. Retrieved from voxeu.org: https://voxeu.org/article/coronavirus-perceptions-and-economic-anxiety.

Fornaro, L., \& Wolf, M. (2020, March 25). Covid-19 Coronavirus and Macroeconomic Policy. Centre for Economic Policy Research.

Franck, T. (2020, May 8). Hardest-bit industries: Nearly half the leisure and hospitality jobs were lost in April. Retrieved from www.cnbc.com: https://www.cnbc.com/2020/05/08/these-industries-suffered-the-biggest-job-lossesin-april-2020.html.

Gita Gopinath. (2020, April 14). The Great Lockdown: Worst Economic Downturn since the Great Depression. International Monetary Fund.

Gooding, A. E., \& O'Malley, T. P. (1977). Market Phase and the Stationarity of Beta. The Journal of Financial and Quantitative Analysis, 833-857.

Greene, W. H. (1997). Econometric Analysis. In W. H. Greene, Econometric Analysis. Macmillan Publishing Company.

Guo, Y.-R., Cao, Q.-D., Hong, Z.-S., Tan, Y.-Y., Chen, S.-D., Jin, H.-J., Yan, Y. (2020). The origin, transmission and clinical therapies on coronavirus disease 2019 (COVID-19) outbreak - an update on the status. Military Medical Research, 7(11). doi:https:/ / doi.org/10.1186/s40779-020-00240-0

Hoque, A., Shikha, F. A., Hasanat, M. W., Arif, I., \& Hamid, D. A. (2020). The Effect of Coronavirus (COVID19) in the Tourism Industry in China. Asian Journal of Multidisciplinary Studies.

Hsu, D. A. (1984). The Behavior of Stock Returns: Is it Stationary of Evolutionary? The Journal of Financial and Quantitative Analysis, 11-28.

International Labour Organization. (2020). International Labour Organization. Retrieved from www.ilo.org: https:/ /www.ilo.org/wcmsp5/groups/public/_ed_dialogue/—sector/documents/briefingnote/ wcms_741468.pdf.

Investopedia. (2020). Investopedia. Retrieved from Durbin Watson Statistic Definition: https:// www.investopedia.com/terms/d/durbin-watson-statistic.asp

Jagannathan, R., \& Wang, Z. (2002, December 17). Empirical Evaluation of Asset Pricing Models: A Comparison of the SDF and Beta Methods. The Journal of Finance, 57(5), 2337-2367. doi:https://doi.org/10.1111/15406261.00498

Jawadi, F., Louhichi, W., Cheffou Idi, A., \& Ben Ameur, H. (2019). Modeling time-varying beta in a sustainable stock market with a three-regime threshold GARCH model. Annals of Operations Research, 275-295.

Joel Shannon. (2020, January 11). Coronavirus has been declared a pandemic: What does that mean, and what took so long? Retrieved from www.usatoday.com: https://www.usatoday.com/story/news/nation/2020/ 03/11/coronavirus-pandemic-world-health-organization/5011903002/

K.Kayo, E., Martelanc, R., O.Brunaldi, E., \& E.da Silva, W. (2020). Capital asset pricing model, beta stability, and the pricing puzzle of electricity transmission in Brazil. Energy Policy. 
Kasare, K. S. (2020). Effects of Coronavirus Disease (COVID -19) on Tourism Industry of India. Studies in Indian Place Names, 40(35).

Lai, C.-C., Shih, T.-P., Ko, W.-C., Tang, H.-J., \& Hsueh, P.-R. (2020, March). Severe acute respiratory syndrome coronavirus 2 (SARS-CoV-2) and coronavirus disease-2019 (COVID-19): The epidemic and the challenges. International Journal of Antimicrobial Agents, 55(3).

Levy, R. A. (1971). On the Short-Term Stationarity of Beta Coefficients. Financial Analysts Journal, 55-62.

Li, C., \& Lalani, F. (2020, April 20). World Economic Forum. Retrieved from www.weforum.org: https:// www.weforum.org/agenda/2020/04/coronavirus-education-global-covid19-online-digital-learning/

Ma, C., Rogers, J., \& Zhou, S. (2020, May 13). Modern health crises: Recession and recovery. Retrieved from voxeu.org: https://voxeu.org/article/modern-health-crises-recession-and-recovery

Mensah, I. (2020, May 13). Unpacking the Impacts of COVID-19 on Tourism and Repackaging The Hotel Service. Retrieved from www.hospitalitynet.org: https://www.hospitalitynet.org/opinion/4098657.html

Nicola, M., Al Safi, Z., Sohrabi, C., Kerwan, A., Al-Jabir, A., Losifidis, C., Agha, R. (2020, June). The socioeconomic implications of the coronavirus pandemic (COVID-19): A review. International Journal of Surgery, 78, 185-193. doi:https://doi.org/10.1016/j.ijsu.2020.04.018

Odabasi, A. (2000). Evidence on the Stationarity of Beta Coefficients: The Case of Turkey. 1-17: Bogazici University, Bebek, Istanbul, Turkey.

Organization for Economic Co-operation and Development, Economic Outlook. (2020, June). Retrieved from http:/ /www.oecd.org/: http://www.oecd.org/economic-outlook/\#Key-impacts

Ozili, P., \& Thankom, A. (2020, April 24). Spillover of COVID-19: Impact on the Global Economy. SSRN.

Park, J.-h. (2013). Calendar Effect: Do Investors Overreact to the Seasonality of the U.S. Hotel Industry? International Journal of Tourism Sciences, 80-102.

Reuters World News. (2020, March 10). Retrieved from www.reuters.com: https://www.reuters.com/article/ushealth-coronavirus-italy-conte-idUSKBN20W2XZ

Sharpe, W. F. (2018, Decemeber 31). Risk, Market Sensitivity and Diversification. Financial Analysts Journal, 74-79. doi:https://doi.org/10.2469/faj.v28.n1.74

Simon, D. S., Pagini, M. L., \& Decourt, R. F. (n.d.). An Analysis of the Beta Coefficient's Stationarity regarding Brazilian Public Companies Traded Between 2002 And 2011.

Singhal, T. (2020). A Review of Coronavirus Disease-2019 (COVID-19). The Indian Journal of Pediatrics, 281-286.

Smedley, M. (2020, May 8). The importance of wearing masks. Retrieved from www.wndu.com: https:// www.wndu.com/content/news/FACT-CHECK-The-importance-of-wearing-masks-570313101.html

Smith, A., \& Freedman, D. (2020, February 13). Isolation, quarantine, social distancing and community containment: pivotal role for old-style public health measures in the novel coronavirus (2019-nCoV) outbreak. Journal of Travel Medicine, 27(2). doi:10.1093/jtm/taaa020

Sohrabia, C., Alsafi, Z., O’Neill, N., Khan, M., Kerwan, A., Al-Jabir, A., Agha, R. (2020, April). World Health Organization declares global emergency: A review of the 2019 novel coronavirus (COVID-19). International Journal of Surgery, 76, 71-76. doi:https://doi.org/10.1016/j.ijsu.2020.02.034

UNESCO. (2020). Retrieved from en.unesco.org: https://en.unesco.org/covid19/educationresponse

United Nations World Tourism Organisation. (2020, March). Impact Assessment of the Covid-19 Outbreak on 
International Tourism. Retrieved from www.unwto.org: https://www.unwto.org/impact-assessment-of-thecovid-19-outbreak-on-international-tourism

Vaitilingam, R. (2020, March 14). Likelihood of a coronavirus recession: Views of leading US and European economists. Retrieved from voxeu.org: https://voxeu.org/article/economic-impact-pandemic-igm-forumsurvey

Verma, R., \& Soydemir, G. (2010, June 7). The Impact of U.S. Individual and Institutional Investor Sentiment on Foreign Stock Markets. Journal of Behavioural Finance, 128-144. doi:https://doi.org/10.1207/ s15427579jpfm0703_2

Wang, L. (2021). Time-varying conditional beta, return spillovers, and dynamic bank diversification strategies. The Quarterly Review of Economics and Finance, 272-280.

World Health Organisation. (2020, January 12). Emergencies preparedness, response - Novel Coronavirus China. Retrieved from www.who.int: https://www.who.int/csr/don/12-january-2020-novel-coronaviruschina/en/

World Health Organization. (2020, April 27). WHO Timeline - COVID-19. Retrieved from www.who.int: https:/ /www.who.int/news-room/detail/27-04-2020-who-timeline-covid-19

World Health Organisation. (2020). Corona virus. Retrieved from www.who.int.

World Tourism Barometer. (2018). Retrieved from www.unwto.org: https://www.unwto.org/global/publication/ unwto-world-tourism-barometer-and-statistical-annex-november-2018

World Trade Organisation. (2020). Retrieved from www.wto.org: https://www.wto.org/english/news_e/pres20_e/ pr855_e.htm

Worldometer. (2020, June 8). Retrieved from www.worldometers.info: https://www.worldometers.info/ coronavirus/

Worldometer COVID-19 Coronarius Pandemic. (2020, June 8). Retrieved from www.worldometers.info: https:/ /www.worldometers.info/coronavirus/

Zhanga, D., Hu, M., \& Ji, Q. (2020, April 16). Financial markets under the global pandemic of COVID-19. Finance Research Letters. doi:https://doi.org/10.1016/j.frl.2020.101528Get

Zheng, Y., Goh, E., \& Wen, J. (2020, March 20). The effects of misleading media reports about COVID-19 on Chinese tourists' mental health: a perspective article. Anatolia-An International Journal of Tourism and Hospitality Research, 31(2), 337-340. doi:https://doi.org/10.1080/13032917.2020.1747208 